\title{
Non-invasive prenatal testing: a review of international implementation and challenges
}

This article was published in the following Dove Press journal:

International Journal of Women's Health

16 January 2015

Number of times this article has been viewed

\section{Megan Allyse' \\ Mollie A Minear ${ }^{2}$ \\ Elisa Berson ${ }^{3}$ \\ Shilpa Sridhar ${ }^{3}$ \\ Margaret Rote ${ }^{3}$ \\ Anthony Hung ${ }^{3}$ \\ Subhashini \\ Chandrasekharan ${ }^{4}$}

'Institute for Health and Aging, University of California San Francisco, San Francisco, California, USA, ${ }^{2}$ Duke Science \& Society, Duke University, Durham, NC, USA, ${ }^{3}$ Trinity College of Arts and Sciences, Duke University, Durham, NC, USA; ${ }^{4}$ Duke Global Health Institute, Duke University, Durham, NC, USA
Correspondence: Megan Allyse University of California San Francisco, Box 0646, 333 California St, Laurel Heights, Room 340, San Francisco, CA 94I43, USA

Email megan.allyse@ucsf.edu
Abstract: Noninvasive prenatal genetic testing (NIPT) is an advance in the detection of fetal chromosomal aneuploidies that analyzes cell-free fetal DNA in the blood of a pregnant woman. Since its introduction to clinical practice in Hong Kong in 2011, NIPT has quickly spread across the globe. While many professional societies currently recommend that NIPT be used as a screening method, not a diagnostic test, its high sensitivity (true positive rate) and specificity (true negative rate) make it an attractive alternative to the serum screens and invasive tests currently in use. Professional societies also recommend that NIPT be accompanied by genetic counseling so that families can make informed reproductive choices. If NIPT becomes more widely adopted, States will have to implement regulation and oversight to ensure it fits into existing legal frameworks, with particular attention to returning fetal sex information in areas where sex-based abortions are prevalent. Although there are additional challenges for NIPT uptake in the developing world, including the lack of health care professionals and infrastructure, the use of NIPT in low-resource settings could potentially reduce the need for skilled clinicians who perform invasive testing. Future advances in NIPT technology promise to expand the range of conditions that can be detected, including single gene disorders. With these advances come questions of how to handle incidental findings and variants of unknown significance. Moving forward, it is essential that all stakeholders have a voice in crafting policies to ensure the ethical and equitable use of NIPT across the world.

Keywords: noninvasive prenatal testing (NIPT), implementation, global, ethics, genetic testing, chromosome aneuploidies

\section{Introduction}

In many countries, the use of maternal serum marker screening and ultrasound imaging (ultrasonography) to detect chromosome aneuploidies and other birth defects are a routine part of prenatal care in the first and/or second trimesters. However, both of these approaches suffer from high false positive rates, ranging from $2 \%-7 \%{ }^{1,2}$ If these tests indicate that a fetus is at increased risk of aneuploidy, invasive methods like chorionic villus sampling (CVS) or amniocentesis are recommended for diagnosis. CVS is typically offered around 10-13 weeks gestation, while amniocentesis is offered after 15 weeks. Many women are uncomfortable with invasive testing because of its physical discomfort and the associated $1 \%-2 \%$ risk of procedure-induced miscarriage. ${ }^{3}$

In recent years, a new prenatal test has entered the market and is rapidly changing the prenatal testing paradigm. Non-invasive prenatal testing (NIPT) offers an intermediate step between serum screening and invasive diagnostic testing. NIPT involves 
analyzing the cell-free fetal DNA (cffDNA) present in a sample of maternal blood to determine the likelihood of a fetal aneuploidy. ${ }^{4}$ NIPT is more accurate than serum screening and produces fewer false positives, but is not currently diagnostic. The only physical risks associated with the procedure are those normally associated with a blood draw and there is no risk of miscarriage. cffDNA can be detected in maternal plasma as early as $5-7$ weeks; ${ }^{5}$ however, test results are more accurate after 10 weeks because the amount of cffDNA increases over time. ${ }^{6}$ Currently, NIPT has only been validated in women with an increased risk of fetal aneuploidies; according to the American Congress of Obstetricians and Gynecologists (ACOG), risk factors include: 1) maternal age 35 years or older at delivery; 2) fetal ultrasonographic findings indicating an increased risk of aneuploidy; 3) history of a prior pregnancy with a trisomy; 4) positive test result for aneuploidy, including first trimester, sequential, or integrated screen, or a quadruple screen; or 5) a parental balanced Robertsonian translocation with increased risk of fetal trisomy 13 or trisomy $21 .^{7}$

Circulating cffDNA, RNA, and intact fetal cells can all be used to assess the genetic status of the fetus noninvasively. cffDNA is abundant, stable, and remains in maternal circulation for only a few days after each pregnancy, making it most suitable for pregnancy-specific testing. ${ }^{8}$ Furthermore, recent innovations in DNA sequencing, such as shotgun massively parallel sequencing (MPS), allow faster and cheaper sequencing of cell-free DNA in maternal circulation. These technologies make it feasible to identify and quantify changes in the amount of fetal chromosomal DNA that signal the presence of a chromosome aneuploidy. Targeted MPS involves sequencing selected regions of interest, such as chromosomes 13, 18, and 21, in cffDNA to determine aneuploidy status. Other methods, such as digital polymerase chain reaction (PCR) to examine methylated DNA and epigenetic differences between fetal and maternal DNA, are currently under exploration for detecting chromosomal aneuploidies via NIPT..$^{8-13}$

Clinical translation of NIPT technologies has advanced rapidly. ${ }^{14}$ As of 2014, commercially available NIPT identifies aneuploidies in chromosomes 13, 16, 18, 21, 22, X, and $\mathrm{Y}$, allowing for detection of the most frequently observed chromosome aneuploidies, including Down syndrome (trisomy 21, or 47,+21), Edward syndrome (trisomy 18, or $47,+18$ ), Patau syndrome (trisomy 13 , or $47,+13$ ), and common sex chromosome aneuploidies like Turner syndrome $(45, X)$ and Klinefelter syndrome $(47, X X Y) .{ }^{15-22}$

Both shotgun and targeted methods of cffDNA sequencing have reported sensitivity (true positive rate) and specificity (true negative rate) rates of greater than $99 \%$ in detecting $47,+21 .^{23-25}$ Sensitivity and specificity are lower for other aneuploidies like 47,+18 (97\%-99\% and $>99 \%$, respectively), 47,+13 (87\%-99\% and $>99 \%$, respectively), and 45,X (92\%-95\% and $99 \%$, respectively), which are comparatively rare. ${ }^{16-22,26-30}$ The low false positive rate $(1 \%-3 \%)$ is one of the most advertised advantages of NIPT; fewer positive findings may allow women to avoid unnecessary invasive procedures to confirm an inaccurate screening result. ${ }^{31,32}$ Although the miscarriage rates for invasive procedures are small, approximately $1 \%$ if performed by a skilled provider, ${ }^{33}$ this risk may be elevated in low resource situations where skilled providers are less prevalent. Studies report that the potential risk to pregnancy, however small, due to invasive procedures is one of the most commonly reported reasons for refusing prenatal diagnosis. ${ }^{34,35}$

NIPT can also determine paternity and fetal sex earlier in gestation than previous tests, including, possibly, ultrasound..$^{36}$ It is also used in parts of Europe to determine fetal rhesus D status and prevent rhesus D negative mothers from undergoing unnecessary prophylactic treatment. ${ }^{37,38}$ Proof of concept has also been demonstrated for the noninvasive detection of sub-chromosomal abnormalities such as copy number variants or microdeletions, which may lead to a variety of conditions involving physical abnormality and cognitive delay. ${ }^{39}$ As of 2014 , tests are commercially available for abnormalities on chromosomes 1p, 5p, 15q, 22q, $11 \mathrm{q}, 8 \mathrm{q}$, and $4 \mathrm{p} .{ }^{40,41}$ The specificity and sensitivity of these tests, however, has not yet been validated. Some groups have also used cffDNA for noninvasive diagnosis of Mendelian, or single gene, disorders. ${ }^{42-44}$ Finally, two groups have demonstrated the potential of sequencing an entire fetal genome using cffDNA ${ }^{45,46}$ but this technique is currently impractical for widespread use and is not recommended by professional societies.

\section{Commercialization}

NIPT was first released in Hong Kong in August $2011^{47}$ and soon after was introduced commercially in the US in October $2011 .^{48,49}$ As of 2014, five for-profit companies offer NIPT in the US. The global NIPT market was valued at US\$0.22 billion in 2012 and is estimated to grow to reach an estimated value of $\$ 3.62$ billion in $2019 .^{50}$ In the US, the first available test was the MaterniT21Plus ${ }^{\text {TM }}$ test developed by Sequenom (San Diego, CA, USA), which currently detects trisomies 13, 16, 18, 21, and 22; certain sex chromosome aneuploidies; and some microdeletions. ${ }^{25}$ Verinata Health, a subsidiary of Illumina (Redwood City, CA, USA), offers verifi ${ }^{\mathrm{TM}}$; the basic test detects trisomies 13,18 , and 21 , and the expanded test 
also reports sex chromosome aneuploidies. ${ }^{23}$ The Harmony ${ }^{\mathrm{TM}}$ Prenatal Test by Ariosa Diagnostics (San Jose, CA, USA) tests for trisomies 13, 18, and 21. ${ }^{51}$ Natera (San Carlos, CA, USA) offers the Panorama ${ }^{\mathrm{TM}}$ test which detects trisomies 13, 18 , and 21 as well as some sex chromosome aneuploidies and some microdeletions. ${ }^{24}$ Finally, LabCorp, Inc. offers the informaSeq ${ }^{\mathrm{SM}}$ test; the basic test detects trisomies 13,18 , and 21 , and additional optional testing testing can detect fetal sex or fetal sex in combination with sex chromosome aneuploidies. ${ }^{52}$ While Sequenom and Verinata use the shotgun MPS approach, Natera and Ariosa use targeted MPS. All four tests can detect fetal sex, but physicians may need to request this information.

Since 2011, several companies have marketed NIPT worldwide. Currently, NIPT is offered in over 60 countries throughout six continents (Figure 1), although a recent market report shows that North America accounts for $64.5 \%$ of global NIPT revenue, followed by Europe. ${ }^{50}$ Sequenom, Verinata Health, Ariosa Diagnostics, Natera, and LabCorp, Inc. distribute from the United States; Iviomics and LifeCodexx are based in Europe; and Berry Genomics and BGI based are based in the People's Republic of China. While all companies offer testing for common chromosomal aneuploidies (trisomies 13, 18, and 21 ), coverage of sex chromosome aneuploidies and fetal sex varies by company and country. Distributing partners, such as laboratories and pregnancy clinics, generally collect samples locally and ship them to laboratories for processing. NIPT is not currently marketed directly to consumers and must be ordered by a physician.

In many countries, multiple companies and their distribution partners offer several tests. Many companies and partners also operate regionally; for example, LifeCodexx offers its test largely within Europe, the Middle East, and Northern Africa, while BGI offers its test largely in Asia, Europe, South America, and the Middle East. Test prices are highly variable across the globe. In the US, test prices range from $\$ 795$ to over $\$ 3,000$, with inconsistent insurance coverage, while invasive procedures like amniocentesis or CVS are nearly always covered by public or private insurance. In Europe, NIPT prices range from $€ 631-858^{49}$ and in the UK range from $£ 400-900 .{ }^{53}$ Elsewhere, NIPT prices in Hong Kong are approximately 4,500 to 8,000 Hong Kong Dollars (US\$580 to \$1,000), and 3,500 real (US\$1492) in Brazil. ${ }^{49}$ Prices in many low- or middle-income countries (LMICs) are not yet available or published. ${ }^{49}$

\section{Implementation in high-income countries}

Although clinicians in the US have adopted NIPT more quickly than anticipated, ${ }^{54-56}$ its availability remains variable. Among four regionally dispersed US medical centers offering

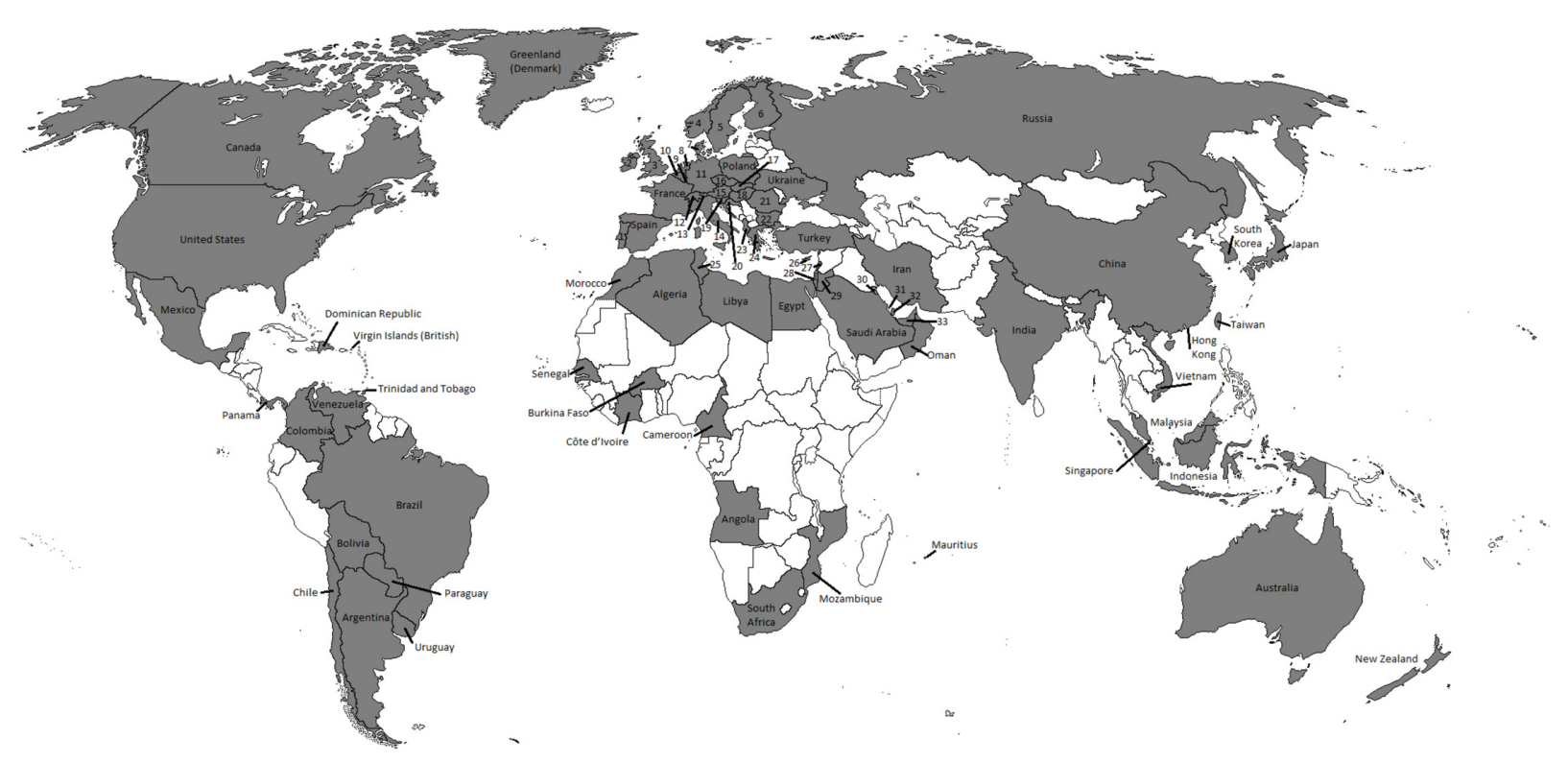

Figure I Global availability of noninvasive prenatal genetic testing (NIPT).

Notes: Countries where NIPT is currently marketed or in which marketing deals have been signed are presented. The list of countries was generated from Internet searches of press releases, company websites, industry trade reports, and newspapers/popular press articles between January I, 20I2 and April 30, 20I4. The list is not exhaustive, as we relied only on publicly available information in English. Only commercial offerings of NIPT for chromosomal aneuploidies using cell-free fetal DNA are included. Numbered countries are as follows: I) Portugal, 2) Ireland, 3) United Kingdom, 4) Norway, 5) Sweden, 6) Finland, 7) Denmark, 8) the Netherlands, 9) Luxembourg, 10) Belgium, II) Germany, 12) Switzerland, (3) Liechtenstein, 14) Italy, I5) Austria, 16) Czech Republic, 17) Slovakia, 18) Hungary, 19) Slovenia, 20) Croatia, 21) Romania, 22) Bulgaria, 23) Albania, 24) Greece, 25) Tunisia, 26) Cyprus, 27) Lebanon, 28) Israel, 29) Jordan, 30) Kuwait, 3I) Bahrain, 32) Qatar, and 33) United Arab Emirates. 
Verinata's test in 2012, there was less testing performed in the Midwest compared to the West and East Coasts. ${ }^{57}$ Private insurance and state Medicaid coverage are also highly variable; some state Medicaid programs do not cover NIPT while other programs will cover NIPT but only from certain companies. There is also a concern that as the use of NIPT increases, the availability and quality of invasive testing will decrease, as clinicians lose practice with performing these technical procedures. Additionally, clinicians will need to ensure that patients are adequately counseled to make autonomous, informed decisions regarding whether to undergo NIPT and how to understand its results and limitations. Finally, questions remain about how ongoing legal battles over intellectual property (IP) in the US will affect test availability and prices, what role government regulatory bodies should play in testing oversight, and how widespread use of NIPT may impact support systems for children born with genetic disorders like Down syndrome.

\section{Clinical issues}

The current standard of care for prenatal screening in many high-income countries involves a first and second trimester ultrasound combined with biomarker serum screens in the first and/or second trimesters. Serum screening provides risk information about chromosomal aneuploidy as well as preeclampsia, intrauterine growth restriction, and fetal demise. ${ }^{58}$ NIPT could be implemented into this testing pipeline in one of three ways: as a replacement for serum screening, as an intermediate step between screening and invasive procedures, or as a replacement for invasive testing. ${ }^{59}$ While NIPT is not currently recommended as a first step in screening by many professional societies, it has been accepted as a second tier test in high-risk pregnancies. ${ }^{7,60-62}$ Nevertheless, studies have been conducted to validate the clinical utility of NIPT in "low risk" pregnancies. ${ }^{15,27,63}$ These studies indicate that NIPT produces lower false positives and higher positive predictive values than serum screening. A recent survey indicated that clinicians believe that NIPT will someday replace conventional screening procedures. ${ }^{58}$

Clinical uptake of NIPT in the US appears to be high. A recent survey of maternal fetal medicine (MFM) specialists revealed that $94 \%$ of 278 respondents currently offer NIPT. ${ }^{58}$ Those who did not cited excessive test cost, lack of insurance coverage, and doubts regarding test sensitivity. Despite the lack of clinical data on NIPT use for average risk pregnancies, and the recommendations of professional societies, $5 \%$ of respondents reported that they offer NIPT to all patients. Over half of respondents also indicated that they offer NIPT when specifically asked by the patient. In addition, 13\% indicated that they offer NIPT as a diagnostic test, again in contrast to professional guidelines, but these respondents reported having less access to genetic counselors than respondents who offer NIPT as a screening method. Despite the fact that $91 \%$ of respondents reported feeling confident in their knowledge of NIPT, these survey results indicate that education gaps remain among MFM specialists regarding the limitations of NIPT and current professional practice guidelines.

These gaps are more significant among clinicians who are not MFM specialists. For instance, MFM specialists may have the training necessary to understand the importance of fetal fraction (the amount of fetal DNA among total circulating cell-free DNA in maternal serum) in determining the accuracy of NIPT. ${ }^{64}$ Fetal fraction can be greatly influenced by maternal body mass index, ethnicity, gestational age, type of aneuploidy, singleton pregnancy versus multiples, and mosaicism. ${ }^{63,65}$ Although the sensitivities and specificities of NIPT are high, they are not diagnostic, and reports in the literature confirm examples of both false positives ${ }^{66}$ and false negatives. ${ }^{67}$ Confined placental mosaicism, maternal mosaicism, co-twin demise, or maternal malignancy ${ }^{29,63}$ have also been reported and can result in false positives. Clinicians may also struggle with clinical management of rare cases where NIPT and invasive testing give discordant results. ${ }^{68}$ Additionally, there have been no head-to-head trials comparing how NIPT tests perform relative to each other, although studies are underway in $\mathrm{Canada}^{69}$ and the UK. ${ }^{70}$ Anecdotally, clinicians are selecting tests based on a variety of factors unrelated to test performance, including average time to receive results, accessibility of customer support services, and technical knowledge of sales representatives. Furthermore, the proprietary nature of the analysis algorithms used by each company hampers the ability to independently validate test results.

Another concern is that the increased uptake of NIPT means fewer invasive procedures will be conducted; indeed, clinics that report an increase in NIPT also report that the number of invasive testing procedures they perform has declined by almost $50 \% .^{57,71}$ Some reports also indicate that women who undergo NIPT based on advanced maternal age opt only for NIPT and decline invasive tests. ${ }^{72}$ While reducing invasive procedures is seen as a benefit from most patients' perspectives, it means that the experience and skill of clinicians who perform these procedures will decline, potentially elevating the risk of procedure-associated miscarriage in each procedure. Additionally, clinicians are at risk of losing licensing credentials if they are unable to perform a specified 
number of these procedures each year. Anecdotally, new generations of MFM specialists are receiving less hands-on practice in amniocentesis or CVS. This may create a cycle wherein the rates of miscarriage associated with invasive testing increase and patients are even more inclined to opt for NIPT over invasive testing. Given that NIPT can produce false positives, there is also a concern that reliance on NIPT will increase the number of healthy fetuses aborted.$^{67}$ Invasive tests also detect chromosome abnormalities, like translocations, inversions, and Mendelian genetic conditions, that are not currently included in commercial NIPT. ${ }^{73}$

Finally, the cost effectiveness of NIPT over other testing and screening protocols must be established. An analysis in Australia indicated that NIPT would increase costs by $9.7 \%$ per case of trisomy 21 confirmed over 2 years, despite the reduction in the number of invasive procedures. ${ }^{74}$ An analysis from the UK indicated that NIPT, when used as a first line test, would produce more favorable outcomes but at greater cost than current testing protocols. ${ }^{53}$ Finally, analyses from the US indicate that using NIPT as an initial screen followed by confirmatory invasive testing is cost-effective compared to the use of NIPT as a diagnostic tool. ${ }^{75}$ An Ariosa-sponsored study also argued that their Harmony ${ }^{\mathrm{TM}}$ test is more effective and cheaper than both first trimester combined screening and integrated screening. ${ }^{27}$

\section{Ethical issues}

One of the major ethical concerns with NIPT is informed decision making. Currently, professional guidelines recommend that patients offered NIPT should receive pre- and posttest genetic counseling; most academic medical centers and MFM specialty clinics in the US provide both. ${ }^{62,76}$ It is less clear whether, and how, clinicians in independent practices offer genetic counseling when they order NIPT directly. There are concerns that NIPT could become "routinized", or merged into the barrage of blood draws that accompany pregnancy visits. ${ }^{77}$ If patients are not given a clear choice about whether or not to undergo NIPT, they may not have an opportunity to think through whether they truly want the test results or how they would react to them. ${ }^{78}$ Data from experiences with serum screening, a "standard" blood draw, indicate poor levels of informed consent prior to undergoing screening, with many women indicating that they did not intend to receive testing or that they declined it without realizing its function. ${ }^{79-81}$ Unexpected test results can have significant emotional and social implications and interfere with reproductive autonomy, which is highly valued in many Western societies. If NIPT replaces the current two-step approach of prenatal screening, it will eliminate this dual opportunity to encourage informed decision-making. ${ }^{59}$ While NIPT as a primary screen could reduce health care costs, it would also allow only one point of contact between a pregnant woman and her physician in which to discuss the implications of undergoing prenatal testing. There is already evidence that both physicians and patients feel there is less need to obtain written consent for NIPT than for invasive testing. ${ }^{82,83}$ As NIPT comes closer to reaching the diagnostic accuracy of invasive testing compared to previous prenatal tests, the ethical implications of how and when NIPT is integrated into prenatal screening need to be carefully weighed. ${ }^{77,84-87}$

There are also logistical considerations in providing patients with the information they need for informed decisionmaking. In countries like Germany, up to $85 \%$ of women opt for serum screening, ${ }^{59}$ if NIPT replaces screening, the resources needed to provide adequate pre-test counseling will increase considerably. There is already a shortage of certified prenatal genetic counselors, prompting concerns that broader adoption of NIPT will result in an overall decrease in informed decision-making. ${ }^{58,64}$ Some companies have begun providing their own genetic counseling services to fill this gap, but observers have raised questions about whether genetic counselors in this position have a conflict of interest. ${ }^{88}$ The lack of genetic counselors further exacerbates concerns that women will have difficulty understanding the risk estimates produced by NIPT, especially that NIPT is not diagnostic and that its sensitivity and specificity vary by condition. ${ }^{78,89-91}$ There are also concerns that women will be less inclined to bond with their future child until they are assured that the fetus is "healthy". 92,93 Some women feel that testing earlier in the pregnancy, and potentially terminating an affected pregnancy, may be easier emotionally because of the "less-intense emotional bond between mother and her unborn child". ${ }^{78}$ Another study reported that the ability of NIPT to detect fetal sex as early as 10 weeks may reassure women who are carriers of $\mathrm{X}$-linked conditions that their child is female, and therefore at lower risk. ${ }^{94}$ These studies suggest that providers will need to be prepared to guide their patients through the interpretation of test results and their implications depending on the context of each pregnancy. However, in the US, fewer and fewer physicians seek board certification in clinical genetics; in fact there are fewer certified annually today than 30 years ago. ${ }^{91}$ Indeed, in states like Alaska, there are no medical geneticists at all, ${ }^{95}$ raising concern about physicians' capability to provide such guidance to patients.

Genetic determinism and eugenics also factor into ethical debates surrounding use of NIPT. Although technological 
limitations and cost currently limit testing to a small number of conditions, future innovations have the potential to expand the spectrum of detectable conditions. There is concern among both physicians and the general public that patients may soon demand testing for a wide variety of conditions, including adult-onset diseases. ${ }^{64,96}$ There is also debate over whether NIPT should be limited to serious medical conditions, and if so what constitutes a serious medical condition. ${ }^{97,98}$ Although factors like the severity of a genetic condition, the viability of the fetus/child, and the quality of life of the family are important considerations, ${ }^{78}$ the variable expressivity and penetrance of genetic disorders, including trisomy 21 , make it difficult to predict the physical or emotional health of an affected child.

These issues will become more prominent if NIPT expands into whole genome microarrays or sequencing. Handling variants of unknown significance (VUS) has already posed problems for invasive microarray testing ${ }^{99-101}$ and pediatric whole genome/exome sequencing. ${ }^{102}$ There is currently no consensus on how to clinically manage $\mathrm{VUS}^{98}$ and when to return these incidental findings to patients. ${ }^{100,101}$

The increasing use of NIPT has important social implications. Mothers of children with Down syndrome report several concerns about the increased uptake of NIPT. ${ }^{103-105}$ Because NIPT testing is "easy", women may feel more pressure to undergo prenatal testing, leading to a potential increase in positive findings. Because statistics suggest that a majority of pregnancies diagnosed with Down syndrome are terminated, increased diagnosis may lead to an increase in terminations. ${ }^{106}$ Activists are concerned that this would increase the social stigma associated with having a child with Down syndrome and the availability of services like medical care, physical or occupational therapy, or school programs for people with Down syndrome. While this population supports the availability of NIPT, they join a consistent narrative from disability rights activists that testing should be provided with balanced information and adequate attention to the psychosocial health of many individuals and families who live happily with conditions like Down syndrome, Turner syndrome, or Klinefelter syndrome. ${ }^{107-110}$ Discussions of how a society continues to value all its members while allowing women and their partners a full range of reproductive autonomy are important and ongoing. ${ }^{104,105}$

\section{Legal and regulatory issues}

NIPT is associated with significant IP issues in the US; four companies have been embroiled in patent litigation since $2011 .^{48}$ Litigation began when Sequenom sought a preliminary injunction against Ariosa to stop marketing its Harmony ${ }^{\mathrm{TM}}$ test, stating that Ariosa's test infringed upon Sequenom's dominant patent. Ariosa counter-sued Sequenom stating that it did not violate the patent. In recent developments, a lower district court rejected Sequenom's request for summary judgment and invalidated several of its patent claims, but an appeal is ongoing. In other battles, Illumina, the parent company of Verinata Health, also sued Ariosa in 2014, arguing that its test also infringed on their IP. ${ }^{111}$ Ongoing administrative proceedings at the US Patent and Trademark Office in patent interference and re-examination cases between Verinata and Sequenom and between Ariosa and Sequenom create further uncertainty. ${ }^{48}$ It is clear that the legal issues will take considerable time and judicial attention to resolve, especially in light of the US Supreme Court's 2013 ruling on the non-patentability of DNA in Association of Molecular Pathology v Myriad. ${ }^{12}$ It is also clear that should any one company prevail, and proceed to block its competitors from providing testing (as Sequenom has stated it intends to do), ${ }^{113}$ the consequences could be significant for patients. Observers of patent monopolies cite increased costs, lack of access to confirmatory testing, and the proprietary retention of data that might otherwise be used to make diagnostic advances as potential negative consequences. ${ }^{114-116}$

All five US companies market NIPT as a laboratorydeveloped test (LDT), and their laboratories are regulated by the Center for Medicare and Medicaid Services under the Clinical Laboratory Improvement Amendments act. The US Food and Drug Administration (FDA) has thus far exercised its discretionary power not to regulate LDTs. However, in 2012 the FDA suggested that it was considering extending oversight over NIPT due to the "high risk" associated with these tests. ${ }^{117}$ Some US companies (Illumina and Sequenom) have also indicated plans to seek premarket approval from the FDA for NIPT test kits going forward. There is no clear consensus in the US about whether NIPT should be regulated by the FDA, especially since several prenatal tests, such as commercially offered prenatal chromosomal microarray tests, are not currently regulated by the FDA and are sold as LDTs. Yet one recent study indicates that nearly half of ACOG fellows favor FDA oversight of NIPT. ${ }^{64}$ In other high-income nations it is not clear that any companies have received regulatory approval from local or regional regulatory agencies. The laboratories of licensed providers of US tests, such as LifeCodexx, are presumably regulated by European regulatory agencies that oversee and certify diagnostic laboratories, but it is not clear that these tests have received approval from European regulatory agencies. 
Like all new reproductive and prenatal technologies, NIPT must comply with existing legal frameworks surrounding reproductive technologies and abortion. Implementation of NIPT could be of particular importance in countries like the US, where gestational limitations on abortion vary by state. Because NIPT can be performed as early as 10 weeks, families may be able to terminate affected pregnancies within the legally allowed gestational age and have more time to consider termination decisions. Earlier access to prenatal information may also allow for medical, rather than surgical abortions, which women may prefer because they are less invasive. ${ }^{118}$ In the future, the range of conditions detected by NIPT may include common Mendelian conditions and a broader range of sub-chromosomal conditions, which may provide families with accurate information about these conditions within the legal abortion timeframe.

\section{Implementation in LMICs}

The availability of prenatal genetic technologies varies drastically in the developing world. Urbanized areas, in which most upper and upper-middle class individuals live, have more information about and access to prenatal testing. ${ }^{32,119}$ Rural areas, urban slums, and other resource-poor regions lack access to most prenatal care. ${ }^{120}$ NIPT uptake is more likely in patients with higher levels of education, higher income, and insurance coverage, factors that are more prevalent in high-income countries than in LMICs. ${ }^{121,122}$ These endemic disparities in LMICs may be exacerbated by both the cost of NIPT and its availability only in specialty clinics in urban areas.

\section{Clinical issues}

In many LMICs, there is less emphasis on prenatal screening for aneuploidy because the incidence rate is lower than in high-income countries. For example, in India only one in every 1,150 live births is born with Down syndrome, as opposed to the one in 732 in the US. ${ }^{123}$ This is partially due to the tendency of women in LMICs to have children younger in life. In India, the percentage of mothers who are greater than 35 years old at the time of delivery is only $2 \%-5 \%,{ }^{123}$ in contrast to $8.3 \%$ (as of 2006) in the US. ${ }^{124}$ The exception, however, is Middle Eastern countries, which have a relatively high fertility rate for women over 35 and a higher overall rate of aneuploidies. ${ }^{123}$ The high rate of consanguineous marriages in parts of the Middle East also increases the incidence of birth defects. ${ }^{125}$ However, as LMICs undergo social and economic transition, the primipara age rises. Furthermore, while the incidence of chromosomal aneuploidies may be low in LMICs, they may have a high incidence of other genetic disorders like beta thalassemia and sickle cell disease. ${ }^{126,127}$ Many of these countries currently manage these conditions through premarital or prenatal genetic services. In fact, the high prevalence of these conditions has led some governments to focus their resources on preconception testing and counseling for these heritable traits rather than on the less common and (generally) nonheritable aneuploidies. ${ }^{128,129}$ Nevertheless, many countries in the Middle East, Africa, and South America still lack systematic and widespread prenatal screening programs. ${ }^{130}$

Infrastructure burdens also interfere with implementing NIPT in low-resource settings like rural and peri-urban areas, urban slums, or locations with low population density. In these areas, a majority of health care is provided by nongovernmental organizations that are funded by national and international grants. ${ }^{131,132}$ Rural clinics may lack the ability to transport blood samples to facilities that can perform laboratory-based tests. Implementation will require improvements to existing infrastructure, such as roads and refrigeration, to make transportation of samples more efficient. Both small government clinics and facilities established by non-governmental organizations may also need support in connecting their patients through referrals to other centers that can provide follow-on testing.

In spite of infrastructure challenges, NIPT may be useful in LMICs because it reduces the need for medical professionals who can perform invasive testing procedures and interpret anomalous ultrasound results. Community health workers are fully capable of taking blood draws, which could then be shipped to specialty laboratories for analysis, ${ }^{133}$ improving access to genetic testing for people in rural, peri-urban, and urban settings. Furthermore, many women in LMICs refuse invasive procedures due to socio-cultural and religious reasons surrounding the sanctity of the pregnancy: a survey of pregnant women in Chile found that while $94 \%$ of patients sought nuchal translucency screening, only $38 \%$ said that they would be willing to conduct an invasive diagnostic test. ${ }^{134}$ NIPT could be a valuable alternative to invasive testing, improving detection rates and lowering false positive rates in these areas. However, this would require public sector institutions that provide specialty genetic services to adopt these technologies, which may require outside investment in sequencing technologies and personnel training.

\section{Ethical issues}

Even more so than in high-income countries, genetic literacy and the availability of genetic counseling services are limited in LMICs to highly trained specialists, who tend to cluster in tertiary care facilities in urban areas, if they exist at all. ${ }^{119,130}$ 
Pre-test counseling and assistance with interpreting results is likely to be limited to relatively narrow sectors of the population. Indeed, in some areas of the People's Republic of China anecdotal reports indicate that patients are receiving results directly via text messages, giving them little to no opportunity to seek professional interpretation. Furthermore, clinical care providers in non-urban areas have little, if any, genetic training. This creates the potential for misunderstood results and poor clinical management, even if providers can re-contact patients regarding their results. It is clear that clinicians need additional resources to ensure informed consent and appropriate emotional and clinical support during NIPT.

The for-profit model of NIPT also raises questions about equity in access for those with financial limitations. Private and public insurance coverage in many LMICs is uneven and/or non-existent, meaning that many families are limited in their access to medical services by what they can pay for out of pocket. In Latin America, 20\%-40\% of people do not have access to any kind of health insurance. ${ }^{135}$ In the People's Republic of China, the cost of NIPT is higher than any other screening protocol in the mainland of the People's Republic of China, ${ }^{27}$ costing the equivalent of an average month's income. ${ }^{49}$ Furthermore, where public health care is available, it often covers existing techniques, such as serum screening or amniocentesis, making NIPT less cost effective. ${ }^{136}$ Even if test prices were reduced, obtaining NIPT would still represent a financial burden for low-income families. Unless subsidy programs are developed, this stratification between those with access to prenatal services and those who lack access has the potential to increase disease burden among less advantaged populations. This is especially problematic, as these populations have the fewest resources to care for individuals with special needs.

Furthermore, in many LMICs the birth of a baby with genetic abnormalities is often seen as a burden. ${ }^{137,138}$ In many areas, where pension funds and other safety nets are not prevalent, children are seen as a source of support and care during old age; children with disabilities may threaten the security of the family as a whole. In the People's Republic of China, "the care of children with handicaps strains and violates the Chinese culturally expected order of parental obligations". ${ }^{139}$ Prenatal testing is therefore seen as a necessity in preventing the birth of disabled children. In a Chinese sample, $78 \%$ of respondents would not consider bearing a child with a $5 \%$ risk of a "handicap" and 83\% said they would seek an abortion if they received such a diagnosis. ${ }^{140}$ These statistics support concerns by many activists that the wider availability of NIPT will lead to an increase in women seeking abortions, and, in some places where abortion is illegal, in women receiving unsafe abortions. This increase not only poses a risk to maternal health but also decreases the number of individuals of differential abilities in these societies. As disability activists have repeatedly argued, the fewer individuals with disabilities who are present in a society, the less that society will learn to value such individuals and provide the necessary services for them to survive and thrive. ${ }^{103,105}$

\section{Legal and regulatory issues}

Since much of the NIPT currently offered in LMICs is performed in US or Europe based-laboratories, only the laboratory accreditation/oversight mechanisms in US and/or Europe apply. Genetic testing in LMICs is not generally under national regulatory oversight but recent events in the People's Republic of China highlight how regulatory issues can affect clinical implementation. In early 2014, the Chinese FDA issued a notice that all clinical sequencing tests in the People's Republic of China would be suspended until they could be evaluated for quality and reliability. ${ }^{141}$ Because a large percentage of the clinical sequencing performed in the People's Republic of China is NIPT, conducted by BGI and Berry Genomics, this ban has a disproportionate impact on the prenatal testing community. Furthermore, because it is illegal to transport DNA out of the country, patients cannot access testing by other international NIPT companies. BGI confirmed that it had ceased all NIPT in the People's Republic of China, ${ }^{142}$ although they eventually received permission to resume testing later in $2014 .{ }^{143}$ It does not appear that the ban ever applied to NIPT that BGI offers globally, where samples enter the People's Republic of China from other countries and are processed in BGI's Shenzen facility. As genetic and genomic tests are marketed globally, more countries will be pressured to develop regulatory frameworks for effective oversight.

There are legal considerations surrounding the use of prenatal testing technologies in LMICs, including national laws on abortion and reproductive technologies. There is ongoing debate about whether prenatal diagnosis should be offered at all in countries where women do not have access to legal abortion. ${ }^{144}$ On one hand, prenatal detection of fetal aneuploidy gives families time to prepare for the birth, arrange resources to deal with potential complications, and schedule specialty services. On the other hand, receiving prenatal information without the option of discontinuing the pregnancy may have moral and psychological consequences. ${ }^{144}$

Laws regarding abortion are highly variable. ${ }^{145}$ Limitations can be placed on the grounds for abortion, or on the gestational 
age limit. In some instances, countries maintain the same restrictions on the reasons for abortion throughout the pregnancy. Other countries incorporate gestational limits within the pregnancy and increasingly limit the grounds for abortion as the pregnancy progresses. ${ }^{146}$ In recent years, there has been indication of a trend toward the liberalization of abortion laws, ${ }^{145}$ but this trend has not been universal. Indeed, some countries have amended their penal codes to further restrict abortion: both El Salvador and Nicaragua removed all exceptions to the prohibition of abortion in 1998 and 2006, respectively. ${ }^{147}$

Numerous factors contribute to the development of abortion laws. In many cases, religion has a prominent influence, ${ }^{146,148}$ but other factors include political ideology and the perceived economic threat of population expansion. ${ }^{146}$ Furthermore, there are often significant discrepancies between abortion policy and practice. ${ }^{146}$ Some question the efficacy of abortion laws altogether, noting that women often seek illegal abortions for unplanned pregnancies. ${ }^{149}$ An estimated $40 \%$ of women around the world live in countries where access to abortion services is restricted; as BernabeOrtiz et al point out, "in 2003, an estimated 55\% of induced abortions in developing countries were unsafe, and $97 \%$ of all unsafe abortions were in developing countries". ${ }^{150}$ This leads to a correlation between restrictive abortion policies, unsafe abortions, and increased maternal mortality. ${ }^{151}$ In jurisdictions where abortion is restricted, women may also travel outside the country to obtain abortion services, often at a high financial and social cost. ${ }^{152,153}$

Another legal issue is the regulation of fetal sex information in countries where sex selection is common practice. In India, the People's Republic of China, and many parts of southeast Asia, sex selection against female children is prevalent, and sex-selective abortion has contributed to highly skewed sex ratios in these countries. ${ }^{154}$ India and the People's Republic of China have enacted legislation forbidding the disclosure of fetal sex information to pregnant women. In India, the national Pre-Conception and Pre-Natal Diagnostics Techniques Act of 1994 prohibits sex-selective abortions, although it did not go into effect until 2003. ${ }^{155,156}$ There is debate about the extent to which this law has reduced sexselective abortion; the child sex ratio at birth has continuously declined from 1971 to $2011 .^{157,158}$ Even with the law in place, however, medical practitioners have several opportunities to covertly disclose fetal sex information to patients ${ }^{154,159}$ and the number of reported violations has risen annually. Some doctors who violated the law were recently prosecuted in India, ${ }^{155}$ but observers warn that enforcement of the law is poor and inconsistent. ${ }^{157}$
In the People's Republic of China, similar legislation has been passed to deter sex-selective abortion, but as in India these laws are unevenly enforced. ${ }^{154,160,161}$ Culturally, there is a strong preference for having at least one male child in the People's Republic of China, due in part to their perceived ability to support their parents during old age. ${ }^{162,163}$ Because the People's Republic of China restricts the number of children families are permitted to have (which varies between jurisdictions, but in urban areas is generally capped at one), families feel enormous pressure to ensure that their only child is male. ${ }^{154}$ As a result, the reported sex ratio at birth in 2003 was roughly 117 boys to 100 girls ${ }^{164}$ in some regions of the People's Republic of China, meaning that 30 to 40 million girls are "missing". ${ }^{165}$ Lai-wan et al refer to the state of sex ratios in the People's Republic of China as an incipient "social and demographic disaster of major proportions for which neither the government nor the people of the People's Republic of China appear to have the will or the means to forestall". ${ }^{166}$ In 2014, transporting blood samples over the border into Hong Kong in order to receive fetal sex testing remains common. ${ }^{167}$

\section{Conclusions and future considerations}

As NIPT expands, it is important that it is used effectively and ethically, especially if it ultimately becomes a first tier screen. Educating patients to ensure informed decision making and reproductive autonomy will be especially challenging in regions with low genetic literacy and few genetic specialists. It will be crucial to train more genetic counselors and to educate clinicians on how to guide women through the complicated and emotional decisions they will encounter as prenatal testing options expand. As sequencing technologies continue to improve, the number of genetic conditions that can be detected noninvasively will increase. Going forward, NIPT is likely to include many more microdeletions, microduplications, and mutations for Mendelian single gene disorders. ${ }^{58}$ The imminent inclusion of single gene disorders like thalassemias or sickle cell disease may be particularly useful for countries where these conditions are prevalent. Local governments and health care systems may wish to develop in-house testing capacity to customize content and focus their limited health care resources.

NIPT is currently too expensive for the majority of people in low-income countries, and these governments generally cannot afford to subsidize it. If LMICs choose to implement NIPT, the most equitable scenario would be to include it in public health sector institutions. But this will require considerable capacity building, investment in sequencing 
capacity, and training for public health professionals. Despite the continuing decline in sequencing costs, there remains a need for technological innovation directed at low-resource settings in order to make NIPT comparable to, or cheaper than, maternal serum screening. Tests that can detect both chromosomal aneuploidies and single gene disorders, and can be used in low-resource settings, will facilitate broader adoption of NIPT in LMICs. In addition, systems for evaluating and sharing national experiences with NIPT will be helpful in developing appropriate, contextspecific practice guidelines. Similarly, better referral systems between community clinics, where most patients are seen, and specialty genetics services, where advanced prenatal testing and clinical care is delivered, will improve access to and use of NIPT. While it is important to train physicians about NIPT best practices, it is even more crucial to train community health workers on the front lines of prenatal care. Finally, these efforts must fit within the regulatory and legal context of each country.

Ultimately, all stakeholders, including professional societies, clinicians, patients, public and private insurance providers, health ministries, local governments, and health care regulators must be engaged in the global implementation of NIPT. The inclusion of these diverse perspectives can guide NIPT policy development to ensure improved prenatal care and health outcomes worldwide.

\section{Acknowledgments}

SC is supported by R01HG007074. SC and MAM are supported by P50HG03391. All authors acknowledge support from the Duke University Bass Connections initiative.

\section{Disclosure}

The authors have no conflicts of interest to declare.

\section{References}

1. Shamshirsaz AA, Benn P, Egan JF. The role of second-trimester serum screening in the post-first-trimester screening era. Clin Lab Med. 2010;30(3):667-676.

2. Russo ML, Blakemore KJ. A historical and practical review of first trimester aneuploidy screening. Semin Fetal Neonatal Med. 2014;19(3): $183-187$.

3. Norwitz ER, Levy B. Noninvasive prenatal testing: the future is now. Rev Obstet Gynecol. 2013;6(2):48-62.

4. Lo YM, Corbetta N, Chamberlain PF, et al. Presence of fetal DNA in maternal plasma and serum. Lancet. 1997;350(9076):485-487.

5. Wright CF, Burton H. The use of cell-free fetal nucleic acids in maternal blood for non-invasive prenatal diagnosis. Hum Reprod Update. 2009;15(1):139-151.

6. Chiu RW, Lo YM. Non-invasive prenatal diagnosis by fetal nucleic acid analysis in maternal plasma: the coming of age. Semin Fetal Neonatal Med. 2011;16(2):88-93.
7. The American College of Obstetricians and Gynecologists Committee on Genetics [homepage on the Internet]. The Society for Maternal-Fetal Medicine Publications Committee. Committee Opinion Number 545; 2012. Noninvasive Prenatal Testing for Fetal Aneuploidy. Available from: http://www.acog.org/Resources-And-Publications/CommitteeOpinions/Committee-on-Genetics/Noninvasive-Prenatal-Testing-forFetal-Aneuploidy. Accessed July 28, 2014.

8. Sayres LC, Cho MK. Cell-Free fetal nucleic acid testing: A review of the technology and its applications. Obstet Gynecol Sur. 2011;66(7):431-442.

9. Hall A, Bostanci A, Wright CF. Non-invasive prenatal diagnosis using cell-free fetal DNA technology: Applications and implications. Public Health Genomics. 2010;13(4):246-255.

10. Hung EC, Chiu RW, Lo YM. Detection of circulating fetal nucleic acids: A review of methods and applications. J Clin Pathol. 2009;62(4): 308-313.

11. Boon EM, Faas BH. Benefits and limitations of whole genome versus targeted approaches for noninvasive prenatal testing for fetal aneuploidies. Prenat Diagn. 2013;33(6):563-568.

12. Liao GJ, Gronowski AM, Zhao Z. Non-invasive prenatal testing using cell-free fetal DNA in maternal circulation. Clin Chim Acta. 2014;428: 44-50.

13. Papageorgiou EA, Koumbaris G, Kypri E, Hadjidaniel M, Patsalis PC. The epigenome view: An effort towards non-invasive prenatal diagnosis. Genes. 2014;5(2):310-329.

14. Chiu RW, Lo YM. Noninvasive prenatal diagnosis empowered by high-throughput sequencing. Prenat Diagn. 2012;32(4):401-406.

15. Nicolaides, Syngelaki A, Ashoor G, Birdir, Touzet G. Noninvasive prenatal testing for fetal trisomies in a routinely screened first-trimester population. Am J Obstet Gynecol. 2012;207(5):374. e1-e6.

16. Ashoor G, Syngelaki A, Wang E, et al. Trisomy 13 detection in the first trimester of pregnancy using a chromosome-selective cell-free DNA analysis method. Ultrasound Obstet Gynecol. 2013;41(1):21-25.

17. Zimmermann B, Hill M, Gemelos G, et al. Noninvasive prenatal aneuploidy testing of chromosomes $13,18,21, \mathrm{X}$, and $\mathrm{Y}$, using targeted sequencing of polymorphic loci. Prenat Diagn. 2012;32(13): 1233-1241.

18. Bianchi D, Platt L, Golberg J, Abuhamad A, Sehnert A, Rava R. Genomewide fetal aneuploidy detection by maternal plasma DNA sequencing. Obstet Gynecol. 2012;119(5):890-901.

19. Bianchi DW, Platt LD, Golberg JD, Abuhamad AZ, Sehnert AJ, Rava RP, MatErnal BLood IS Source to Accurately diagnose fetal aneuploidy (MELISSA) Study Group. Genome-Wide fetal aneuploidy detection by maternal plasma DNA sequencing. Obstet Gynecol. 2012;119(5): 890-901.

20. Norton ME, Brar H, Weiss J, et al. Non-Invasive chromosomal evaluation (NICE) study: Results of a multicenter prospective cohort study for detection of fetal trisomy 21 and trisomy 18. Am J Obstet Gynecol. 2012;207(2):137. e1-e8.

21. Palomaki GE, Kloza EM, Lambert-Messerlian GM, et al. DNA sequencing of maternal plasma to detect Down syndrome: An international clinical validation study. Genet Med. 2011;13(11):913-920.

22. Palomaki GE, Deciu C, Kloza EM, et al. DNA sequencing of maternal plasma reliably identifies trisomy 18 and trisomy 13 as well as Down syndrome: An international collaborative study. Genet Med. 2012;14(3): 296-305.

23. Ilumina [homepage on the Internet]. Clinical data; Analytical validation of the verifi ${ }^{\circledR}$ prenatal test: enhanced test performance for detecting trisomies 21, 18, and 13 and the option for classification of sex chromosome status. Available from: http://www.verifitest.com/clinical-data/. Accessed June 15, 2014.

24. Panorama Prenatal Screen [homepage on the Internet]. The next generation of non-invasive prenatal screening. Available from: http:// www.panoramatest.com/clinical_data. Accessed June 15, 2014.

25. Sequenom Laboratories [homepage on the Internet]. The Science of Revolutionizing Prenatal Care. Available from: http://sequenom.uberflip.com/i/212031. Accessed June 15, 2014. 
26. Wald NJ, Bestwick JP. Incorporating DNA sequencing into current prenatal screening practice for down's syndrome. PLoS One. 2013;8(3):e58732.

27. Song K, Musci TJ, Caughey AB. Clinical utility and cost of noninvasive prenatal testing with cfdna analysis in high-risk women based on a US population. J Matern Fetal Neonatal Med. 2013;26(12): 1180-1185.

28. Shaw SW, Chen CP, Cheng PJ. From down syndrome screening to noninvasive prenatal testing: 20 years' experience in taiwan. Taiwan J Obstet Gynecol. 2013;52(4):470-474.

29. Choi H, Lau TK, Jiang FM, et al. Fetal aneuploidy screening by maternal plasma DNA sequencing: 'False positive' due to confined placental mosaicism. Prenat Diagn. 2013;33(2):198-200.

30. Morain, Greene MF, Mello MM. A new era in noninvasive prenatal testing. N Engl J Med. 2013;369(6):499-501.

31. Pollack BA. A less risky Down syndrome test is developed. The New York Times. October 17, 2011. Available from: http://www.nytimes. com/2011/10/18/business/sequenom-test-for-down-syndrome-raiseshopes-and-questions.html?pagewanted=all\&_r=1\&. Accessed August 25, 2014.

32. Dickens BM. Ethical and legal aspects of noninvasive prenatal genetic diagnosis. Int J Gynaecol Obstet. 2014;124(2):181-184.

33. Tabor A, Vestergaard $\mathrm{CH}$, Lidegaard $\varnothing$. Fetal loss rate after chorionic villus sampling and amniocentesis: An 11-year national registry study. Ultrasound Obstet Gynecol. 2009;34(1):19-24.

34. Allyse M, Sayres LC, Goodspeed TA, Cho MK. Attitudes towards noninvasive prenatal testing for aneuploidy among US adults of reproductive age. J Perinatol. 2014;34(6):429-434.

35. Markens S, Browner CH, Press N. 'Because of the risks': How US pregnant women account for refusing prenatal screening. Soc Sci Med. 1999;49(3):359-369.

36. Devaney SA, Palomaki GE, Scott JA, Bianchi DW. Noninvasive fetal sex determination using cell-free fetal DNA: A systematic review and meta-analysis. JAMA. 2011;306(6):627-636.

37. Goodspeed TA, Allyse M, Sayres LC, Norton ME, Cho MK. Translating cell-free fetal DNA technology: Structural lessons from non-invasive RhD blood typing. Trends Biotechnol. 2013;31(1):7-9.

38. Clausen FB. Integration of noninvasive prenatal prediction of fetal blood group into clinical prenatal care. Prenat Diagn. 2014;34(5): 409-415.

39. Vora NL, O’Brien BM. Noninvasive prenatal testing for microdeletion syndromes and expanded trisomies. Obstet Gynecol. 2014;123(5): 1097-1099.

40. Sequenom, Inc. Sequenom laboratories launches the enhanced sequencing series for the Maternit2 $1^{\mathrm{TM}}$ Plus test [press release]. San Diego, CA: Sequenom Laboratories; [October 22, 2013]. Available from: http://www.sequenom.com/press/sequenom-laboratorieslaunches-enhanced-sequencing-series-maternit21-plus-test. Accessed July 28, 2014.

41. Sequenom [webpage on the Internet]. Sequenom Laboratories Presents New Data on the Enhanced Sequencing Series for the MaterniT21 ${ }^{\text {TM }}$ Plus Laboratory-Developed Test At 18th International Conference on Prenatal Diagnosis and Therapy. San Diego, USA, July 22, 2014. Available from: http://www.sequenom.com/press/sequenom-laboratories-presents-newdata-enhanced-sequencing-series-maternit21-plus-laboratory. Accessed August 29, 2014.

42. Lench N, Barrett A, Fielding S, et al. The clinical implementation of non-invasive prenatal diagnosis for single-gene disorders: challenges and progress made. Prenat Diagn. 2013;33(6):555-562.

43. Chitty LS, Bianchi DW. Noninvasive prenatal testing: the paradigm is shifting rapidly. Prenat Diagn. 2013;33(6):511-513.

44. You Y, Sun Y, Li X, et al. Integration of targeted sequencing and NIPT into clinical practice in a Chinese family with maple syrup urine disease. Genet Med. 2014;16(8):594-600.

45. Lo YM, Chan KC, Sun H, et al. Maternal plasma DNA sequencing reveals the genome-wide genetic and mutational profile of the fetus. Sci Transl Med. 2010;2(61):61ra91.
46. Kitzman JO, Snyder MW, Ventura M, et al. Noninvasive whole-genome sequencing of a human fetus. Sci Transl Med. 2012;4(137):137ra76.

47. Lau TK, Chan MK, Lo PS, et al. Clinical utility of noninvasive fetal trisomy (NIFTY) test - early experience. J Matern Fetal Neonatal Med. 2012;25(10):1856-1859.

48. Agarwal A, Sayres LC, Cho MK, Cook-Deegan R, Chandrasekharan S. Commercial landscape of noninvasive prenatal testing in the United States. Prenat Diagn. 2013;33(6):521-531.

49. Chandrasekharan S, Minnear MA, Hung A, Allyse M. Noninvasive prenatal testing goes global. Sci Transl Med. 2014;6(231):231fs15.

50. Transparency Market Research [homepage on the Internet]. Non-Invasive prenatal testing (NIPT) market (maternit21 PLUS, verifi, harmony, panorama, NIFTY, prenatest and bambnitest) - global industry analysis, size, share, growth, trends and forecast, 2013-2019. Available from: http://www.transparencymarketresearch.com/noninvasive-prenataldiagnostics-market.html2014. Accessed June 15, 2014.

51. Ariosa Diagnostics [webpage on the Internet]. Harmony prenatal test clinical data. Available from: http://www.ariosadx.com/review-clinicaldata/clinical-data/. Accessed June 15, 2014.

52. Integrated Genetics [webpage on Internet]. informaSeq Prenatal Test. Available from: https://www.labcorp.com/wps/wcm/connect/IntGeneticsLib/integratedgenetics/home/our+services/reproductive+testing/ informaseq+prenatal+test. Accessed September 2, 2014.

53. Morris S, Karlsen S, Chung N, Hill M, Chitty LS. Model-Based analysis of costs and outcomes of non-invasive prenatal testing for down's syndrome using cell free fetal DNA in the UK national health service. PLoS One. 2014;9(4):e93559.

54. Heger M. As maternit21 drives spike in diagnostic revenue, sequenom predicts 25K tests sold in 2012. Genomeweb. March 14, 2012. Available from: http://www.genomeweb.com/sequencing/maternit21-drivesspike-diagnostic-revenue-sequenom-predicts-25k-tests-sold-2012. Accessed August 29, 2014.

55. Heger M. As rivals vie for share of noninvasive trisomy testing market, physicians see value for screening. GenomeWeb. July 3, 2012. Available from: http:/www.genomeweb.com/sequencing/rivals-vieshare-noninvasive-trisomy-testing-market-physicians-see-value-screeni. Accessed August 29, 2014.

56. Heger M. Sequencing-Based fetal testing market heats up as verinata plans 2012 launch for down syndrome dx. GenomeWeb. May 2, 2011. Available from: http://www.genomeweb.com/sequencing/sequencingbased-fetal-testing-market-heats-verinata-plans-2012-launch-downsynd. Accessed August 29, 2014.

57. Platt LD, Janicki MB, Prosen T, et al. Impact of noninvasive prenatal testing in regionally dispersed medical centers in the United States. Am J Obstet Gynecol. Epub April 3, 2014.

58. Haymon L, Simi E, Moyer K, Aufox S, Ouyang DW. Clinical implementation of noninvasive prenatal testing among maternal fetal medicine specialists. Prenat Diagn. 2014;34(5):416-423.

59. Schmitz D, Netzer C, Henn W. An offer you can't refuse? Ethical implications of non-invasive prenatal diagnosis. Nat Rev Genet. 2009;10(8):515.

60. Gregg AR, Gross SJ, Best RG, et al. ACMG statement on noninvasive prenatal screening for fetal aneuploidy. Genet Med. 2013;15(5): 395-398.

61. Benn P, Borell A, Chiu R, et al. Position statement from the aneuploidy screening committee on behalf of the board of the International Society for Prenatal Diagnosis. Prenat Diagn. 2013;33(7):622-629.

62. [No authors listed]. Position statement from the Italian College of Fetal Maternal Medicine: Non-invasive prenatal testing (NIPT) by maternal plasma DNA sequencing. J Prenat Med. 2013;7(2):19-20.

63. Bianchi D, Parker RL, Wentworth J, et al. DNA sequencing versus standard prenatal aneuploidy screening. NEJM. 2014;370(9):799-808.

64. Benn P, Cuckle H. Theoretical performance of non-invasive prenatal testing for chromosome imbalances using counting of cell-free DNA fragments in maternal plasma. Prenat Diagn. 2014;34(8): 778-783. 
65. Ashoor G, Syngelaki A, Wagner M, Birdir C, Nicolaides KH. Chromosome-selective sequencing of maternal plasma cell-free DNA for first-trimester detection of trisomy 21 and trisomy 18. Am J Obstet Gynecol. 2012;206(4):322. e1-e5.

66. Smith M, Lewis KM, Holmes A, Visootsak J. A case of false negative NIPT for down syndrome-lessons learned. Case Rep Genet. 2014; 2014:823504.

67. Verweij EJ, de Boer MA, Oepkes D. Non-invasive prenatal testing for trisomy 13; more harm than good? Ultrasound Obstet Gynecol. 2014;44(1):112-114.

68. Srebniak MI, Diderich KE, Noomen P, Dijkman A, Vries F, Opstal DV. Abnormal NIPT results concordant with the karyotype of the cytotrophoblast, but not reflecting the abnormal fetal karyotype. Ultrasound Obstet Gynecol. 2014;44(1):109-111.

69. Centre Hospitalier Universitaire de Québec, CHU de Québec. Study of the Efficacy of New Non-invasive Prenatal Tests for Screening for Fetal Trisomies Using Maternal Blood (PEGASUS). Available from: http:// clinicaltrials.gov/show/NCT01925742. NLM identifier: NCT01925742. Accessed July 28, 2014.

70. Reliable Accurate Prenatal non-Invasive Diagnosis [homepage on the Internet]. Guides to NIPD/NIPT. Available from: http://www.rapid.nhs. uk/. Accessed July 28, 2014.

71. Manegold-Brauer G, Kang Bellin A, Hahn S, et al. A new era in prenatal care: Non-invasive prenatal testing in Switzerland. Swiss Med Wkly. 2014;144:w13915.

72. Pettit KE, Hull AD, Korty L, Jones MC, Pretorius DH. Noninvasive prenatal testing: A replacement for chorionic villus sampling and amniocentesis for advanced maternal age? Obstet Gynecol. 2014;123 Suppl 1:165S-166S.

73. Rad S, Turner AL, Beauchamp S, Aghajanian P, Williams J 3rd, Esakoff TF. Noninvasive prenatal testing compared with invasive diagnostic testing in the setting of an abnormal state aneuploidy screen. Obstet Gynecol. 2014;123 Suppl 1:100S.

74. O'Leary P, Maxwell S, Murch A, Hendrie D. Prenatal screening for Down syndrome in Australia: Costs and benefits of current and novel screening strategies. Aust N Z J Obstet Gynaecol. 2013;53(5):425-433.

75. Ohno M, Caughey A. The role of noninvasive prenatal testing as a diagnostic versus a screening tool - a cost-effectiveness analysis. Prenat Diagn. 2013;33(7):630-635.

76. Devers PL, Cronister S, Ormond KE, Facio F, Brasington CK, Flodman P. Noninvasive prenatal testing/noninvasive prenatal diagnosis: The position of the national society of genetic counselors. J Genet Couns. 2013;22(3):291-295.

77. Deans Z, Newson AJ. Should non-invasiveness change informed consent procedures for prenatal diagnosis? Health Care Anal. 2011;19(2): 122-132.

78. van Schendel RV, Kleinveld JH, Dondorp WJ, et al. Attitudes of pregnant women and male partners towards non-invasive prenatal testing and widening the scope of prenatal screening. Eur J Hum Genet. Epub March 19, 2014.

79. Constantine M, Allyse M, Rockwood T, Wall M, De Vries R. Imperfect informed consent for prenatal screening: Lessons from the quad screen. Clinical Ethics. 2014;9(1):17-27.

80. Favre R, Duchange N, Vayssière $\mathrm{C}$, et al. How important is consent in maternal serum screening for Down syndrome in France? Information and consent evaluation in maternal serum screening for Down syndrome: a French study. Prenat Diagn. 2007;27(3):197-205.

81. van den Berg M, Timmermans DR, ten Kate LP, van Vugt JM, van der Wal G. Informed decision making in the context of prenatal screening. Patient Educ Couns. 2006;63(1-2):110-117.

82. van den Heuvel A, Chitty L, Dormandy E, et al. Will the introduction of non-invasive prenatal diagnostic testing erode informed choices? An experimental study of health care professionals. Patient Educ Couns. 2010;78(1):24-28.

83. Silcock C, Liao L-M, Hill M, Chitty LS. Will the introduction of noninvasive prenatal testing for down's syndrome undermine informed choice? Health Expectations. Epub February 20, 2014.

84. Benn PA, Chapman AR. Ethical challenges in providing noninvasive prenatal diagnosis. Curr Opin Obstet Gynecol. 2010;22(2):128-134.
85. Deans Z, Hill M, Chitty LS, Lewis C. Non-invasive prenatal testing for single gene disorders: exploring the ethics. Eur J Hum Genet. 2013;21(7):713-718.

86. de Jong A, Dondorp WJ, Frints SG, de Die-Smulders CE, de Wert GM. Advances in prenatal screening: the ethical dimension. Nat Rev Genet. 2011;12(9):657-663.

87. de Jong A, Dondorp WJ, de Die-Smulders CE, Frints SG, de Wert GM. Non-invasive prenatal testing: ethical issues explored. Eur J Hum Genet. 2010;18(3):272-277.

88. Pollack A. Conflict potential seen in genetic counselors. The New York Times. July 13, 2012.

89. Bensend TA, Veach PM, Niendorf KB. What's the harm? Genetic counselor perceptions of adverse effects of genetics service provision by non-genetics professionals. J Genet Couns. 2014;23(1): 48-63.

90. Horsting JM, Dlouhy SR, Hanson K, Quaid K, Bai S, Hines KA. Genetic counselors' experience with cell-free fetal DNA testing as a prenatal screening option for aneuploidy. J Genet Couns. 2014;23(3): 377-400.

91. Markens S. "It just becomes much more complicated": Genetic counselors' views on genetics and prenatal testing. New Genetics and Society. 2013;32(3):302-321.

92. Rothman BK. The Tentative Pregnancy: How Amniocentesis Changes the Experience of Motherhood. New York: Norton; 1993.

93. Asch A, Wasserman D. Where is the sin in synecdoche? Prenatal testing and the parent-child relationship. In: Quality of Life and Human Difference: Genetic Testing, Health Care, and Disability. New York: Cambridge University Press; 2005:172-216.

94. Costa JM, Benachi A, Gautier E. New strategy for prenatal diagnosis of x-linked disorders. N Engl J Med. 2002;346(19):1502.

95. Maron DF. Virtual doctor visits gaining steam in "geneticist deserts". Scientific American. April 21, 2014. Available from: http://www. scientificamerican.com/article/virtual-doctor-visits-gaining-steam/. Accessed August 25, 2014.

96. Farrimond HR, Kelly SE. Public viewpoints on new non-invasive prenatal genetic tests. Public Underst Sci. 2013;22(6):730-744.

97. Wertz DC, Knoppers BM. Serious genetic disorders: Can or should they be defined? Am J Med Genet. 2002;108(1):29-35.

98. Green RC, Berg JS, Grody WW, et al. ACMG recommendations for reporting of incidental findings in clinical exome and genome sequencing. Genet Med. 2013;15(7):565-574.

99. de Jong A, Dondorp WJ, Macville MV, de Die-Smulders CE, van Lith JM, de Wert GM. Microarrays as a diagnostic tool in prenatal screening strategies: Ethical reflection. Hum Genet. 2014;133(2):163-172.

100. Bernhardt BA, Kellom K, Barbarese A, Faucett WA, Wapner RJ. An exploration of genetic counselors' needs and experiences with prenatal chromosomal microarray testing. J Genet Couns. Epub February 27, 2014.

101. Bernhardt BA, Soucier D, Hanson K, Savage MS, Jackson L, Wapner RJ. Women's experiences receiving abnormal prenatal chromosomal microarray testing results. Genet Med. 2013;15(2):139-145.

102. Tabor HK, Murray JC, Gammill HS, et al. Non-invasive fetal genome sequencing: Opportunities and challenges. Am J Med Genet A. 2012;158A(10):2382-2384.

103. Kellogg G, Slattery L, Hudgins L, Ormond K. Attitudes of mothers of children with down syndrome towards noninvasive prenatal testing. J Genet Couns. Epub February 1, 2014.

104. Parens E, Asch A. Special supplement: The disability rights critique of prenatal genetic testing reflections and recommendations. Hastings Cent Rep. 1999;29(5):S1-S22.

105. Parens E, Asch A. Disability rights critique of prenatal genetic testing: Reflections and recommendations. Ment Retard Dev Disabil Res Rev. 2003;9(1):40-47.

106. Roberts CD, Stough LD, Parrish LH. The role of genetic counseling in the elective termination of pregnancies involving fetuses with disabilities. J Spec Educ. 2002;36(1):48-55. 
107. Skotko BG, Levine SP. What the other children are thinking: Brothers and sisters of persons with down syndrome. Am J Med Genet C Semin Med Genet. 2006;142C(3):180-186.

108. Skotko BG, Levine SP, Goldstein R. Self-perceptions from people with Down syndrome. Am J Med Genet A. 2011;155A(10):2360-2369.

109. Skotko. With new prenatal testing, will babies with Down syndrome disappear? Arch Dis Child. 2009;94(11):823-826.

110. Skotko BG, Levine SP, Goldstein R. Having a son or daughter with Down syndrome: Perspectives from mothers and fathers. Am J Med Genet A. 2011;155A(10):2335-4237.

111. Illumina [homepage on the Internet]. Illumina files new patent infringement suit against ariosa diagnostics, Inc [press release]. [April 25, 2014]. Available from: http://investor.illumina.com/phoenix. zhtml?c=121127\&p=irol-newsArticle \&ID=1922600\&highlight $=$ Accessed August 25, 2014.

112. Graff GD, Phillips D, Lei Z, Oh S, Nottenburg C, Pardey PG. Not quite a myriad of gene patents. Nature Biotechnology. 2013;31(5): 404-410.

113. Sayres LC, Allyse M, Goodspeed TA, Cho MK. In the public interest? Sci Transl Med. 2012;4(144):144fs23.

114. Cook-Deegan R, Chandrasekharan S, Angrist M. The dangers of diagnostic monopolies. Nature. 2009;458(7237):405-406.

115. Cho M. Patently unpatentable: Implications of the myriad court decision on genetic diagnostics. Trends Biotechnol. 2010;28(11):548-551.

116. Cook-Deegan R, Conley JM, Evans JP, Vorhaus D. The next controversy in genetic testing: Clinical data as trade secrets? Eur J Hum Genet. 2013;21(6):585-588.

117. Ray T. Amid 'chaos,' FDA's gutierrez offers insights on agency's regulatory stance on molecular tests. GenomeWeb. February 13, 2013. Available from: http://www.genomeweb.com/clinical-genomics/ amid-chaos-fdas-gutierrez-offers-insights-agencys-regulatory-stancemolecular-te. Accessed August 29, 2014.

118. Moreau C, Trussell J, Desfreres J, Bajos N. Medical vs Surgical abortion: the importance of women's choice. Contraception. 2011; 84(3):224-229.

119. Wu Z, Viisainen K, Li X, Hemminki E. Maternal care in rural China: A case study from anhui province. BMC Health Serv Res. 2008;8:55.

120. Lu J, Shen JJ, Chen G, et al. Regional disparities in prenatal care services in rural China. Asia Pac J Public Health. 2011;23(5):682-689.

121. Tischler R, Hudgins L, Blumenfeld YJ, Greely HT, Ormond KE. Noninvasive prenatal diagnosis: Pregnant women's interest and expected uptake. Prenat Diagn. 2011;31(13):1292-1299.

122. Sayres LC, Allyse M, Goodspeed TA, Cho MK. Demographic and experiential correlates of public attitudes towards cell-free fetal DNA screening. J Genet Couns. Epub April 9, 2014.

123. Verma IC, Lall M, Dua Puri R. Down syndrome in India diagnosis, screening, and prenatal diagnosis. Clin Lab Med. 2012;32(2):231-248.

124. Matthews TJ, Hamilton BE. Delayed childbearing: more women are having their first child later in life. NCHS Data Brief. 2009;(21):1-8.

125. Al-Herz W, Al-Mousa H. Combined immunodeficiency: The Middle East experience. J Allergy Clin Immunol. 2013;131(3):658-660.

126. Abolghasemi H, Amid A, Zeinali S, et al. Thalassemia in Iran: epidemiology, prevention, and management. J Pediatr Hematol Oncol. 2007;29(4):233-238.

127. Diallo DA, Guindo A. Sickle cell disease in sub-Saharan Africa: Stakes and strategies for control of the disease. Curr Opin Hematol. 2014;21(3):210-214.

128. He S, Li D, Lai Y, et al. Prenatal diagnosis of $\beta$-thalassemia in Guangxi Zhuang autonomous region, China. Arch Gynecol Obstet. 2014;289(1):61-65.

129. Fox D. Prenatal screening policy in international perspective: Lessons from Israel, Cyprus, Taiwan, China, and Singapore. Yale Journal of Health Policy, Law, and Ethics. 2013;9(2):5.

130. Christianson A, Modell B. Medical genetics in developing countries. Annu Rev Genomics Hum Genet. 2004;5:219-265.

131. Abou-Zahr CL, Wardlaw TM. Antenatal care in developing countries: Promises, achievements and missed opportunities-an analysis of trends, levels and differentials, 1990-2001. WHO; 2003.
132. Pathak PK, Singh A, Subramanian SV. Economic inequalities in maternal health care: Prenatal care and skilled birth attendance in India, 1992-2006. PLoS One. 2010;5(10):e13593.

133. Bischoff FZ, Lewis DE, Simpson JL. Cell-free fetal DNA in maternal blood: Kinetics, source and structure. Hum Reprod Update. 2005;11(1):59-67.

134. Wong AE, Kuppermann M, Creasman JM, Sepulveda W, Vargas JE. Patient and provider attitudes toward screening for down syndrome in a Latin American country where abortion is illegal. Int J Gynaecol Obstet. 2011;115(3):235-239.

135. Ventura W, Nazario-Redondo C, Sekizawa A. Non-invasive prenatal diagnosis from the perspective of a low-resource country. Int $J$ Gynaecol Obstet. 2013;122(3):270-273.

136. Sahota DS, Leung WC, Chan WP, To WW, Lau ET, Leung TY. Prospective assessment of the Hong Kong hospital authority universal down syndrome screening programme. Hong Kong Med J. 2013;19(2): 101-108.

137. Wang P, Michaels CA. Chinese families of children with severe disabilities: Family needs and available support. Research and Practice for Persons with Severe Disabilities. 2009;34(2):21-32.

138. Bittles AH, Glasson EJ. Clinical, social, and ethical implications of changing life expectancy in Down syndrome. Dev Med Child Neurol. 2004;46(4):282-286.

139. Holroyd EE. Chinese cultural influences on parental caregiving obligations toward children with disabilities. Qual Health Res. 2003;13(1): 4-19.

140. Su B, Macer DR. Chinese people's attitudes towards genetic diseases and children with handicaps. Rev Derecho Genoma Hum. 2003;(18): 191-210.

141. Chen SJ. China cracks down on DNA testing. Forbes. March 3, 2014. Available from http://www.forbes.com/sites/shuchingjeanchen/2014/ 03/03/china-cracks-down-on-dna-testing-2/. Accessed August 25, 2014

142. GenomeWeb Staff Writer. BGI suspends clinical ngs-based trisomy testing in china. GenomeWeb. March 4, 2014. http://www.genomeweb. com/sequencing/bgi-suspends-clinical-ngs-based-trisomy-testingchina

143. Genomeweb [webpage on Internet]. China FDA Approves BGI's NGS Products. July 02, 2104. Available from: http://www.genomeweb.com/ sequencing/china-fda-approves-bgis-ngs-products. Accessed August, 292014.

144. Ballantyne A, Newson A, Luna F, Ashcroft R. Prenatal diagnosis and abortion for congenital abnormalities: Is it ethical to provide one without the other? Am J Bioeth. 2009;9(8):48-56.

145. Finer L, Fine JB. Abortion law around the world: Progress and pushback. Am J Public Health. 2013;103(4):585-589.

146. Finlay JE, Canning D, Po JY. Reproductive health laws around the world. Program on the Global Demography of Aging. 2012. Available from: http://www.hsph.harvard.edu/pgda/wp-content/uploads/ sites/1288/2013/10/PGDA_WP_96.pdf. Accessed August 25, 2104.

147. Boland R, Katzive L. Developments in laws on induced abortion: 1998-2007. Int Fam Plan Perspect. 2008;34(3):110-120.

148. Abbasi M, Gooshki ES, Allahbedashti N. Abortion in Iranian legal system. Iran J Allergy Asthma Immunol. 2014;13(1):71-84.

149. Sedgh G, Singh S, Shah IH, Åhman E, Henshaw SK, Bankole A. Induced abortion: Incidence and trends worldwide from 1995 to 2008. Lancet. 2012;379(9816):625-632.

150. Bernabé-Ortiz A, White PJ, Carcamo CP, et al. Clandestine induced abortion: prevalence, incidence and risk factors among women in a Latin american country. CMAJ. 2009;180(3):298-304.

151. World Health Organization [homepage on the Internet]. Unsafe abortion: Global and regional estimates of incidence of unsafe abortion and associated mortality in 2008. Available from http://www.who.int/ reproductivehealth/publications/unsafe_abortion/9789241501118/en/. Accessed June 15, 2014.

152. Fletcher R. Peripheral governance: Administering transnational health-care flows. International Journal of Law in Context. 2013;9(2): 160-191. 
153. Palmer B. "Lonely, tragic, but legally necessary pilgrimages": transnational abortion travel in the 1970s. Can Hist Rev. 2011;92(4): 637-664.

154. Hvistendahl M. Unnatural Selection: Choosing Boys Over Girls, and The Consequences of A World Full of Men. Reprinted. New York: Public Affairs; 2011.

155. Kay M. Five Tamil Nadu doctors banned from practice for violating prenatal sex selection law. BMJ. 2013;346:f3788.

156. Ministry of Health and Family Welfare, Government of India [homepage on the Internet]. Annual report on implementation of the pre-conception and pre-natal diagnostic techniques (prohibition of sex selection) act 2005. Available from: http://india.unfpa.org/drive/ IMPLEMENTATIONOFTHEPCPNDTACTININDIAPerspectivesandChallenges.pdf. Accessed June 15, 2014.

157. Nandi A, Deolalikar AB. Does a legal ban on sex-selective abortions improve child sex ratios? Evidence from a policy change in India. Journal of Development Economics. 2013;103:216-228.

158. Madan K, Breuning MH. Impact of prenatal technologies on the sex ratio in India: An overview. Genet Med. 2014;16(6):425-432.

159. Jain A. Sex selection and abortion in India. BMJ. 2013;346:f1957.

160. Nie JB. Limits of state intervention in sex-selective abortion: The case of China. Cult Health Sex. 2010;12(2):205-219.
161. French BH. As girls 'vanish,' Chinese city battles tide of abortions. NY Times Web. 2005:A3.

162. Gupta MD, Zhenghua J, Bohua L, Zhenming X, Chung W, Hwa-Ok B. Why is son preference so persistent in east and south Asia? A crosscountry study of China, India and the republic of Korea. The Journal of Development Studies. 2003;40(2):153-187.

163. Hesketh T, Lu L, Xing ZW. The consequences of son preference and sex-selective abortion in china and other Asian countries. CMAJ. 2011;183(12):1374-1377.

164. Plafker T. Sex selection in China sees 117 boys born for every 100 girls. BMJ. 2002;324(7348):1233.

165. Nie JB. Non-medical sex-selective abortion in china: Ethical and public policy issues in the context of 40 million missing females. Br Med Bull. 2011;98(1):7-20.

166. Lai-wan CC, Blyth E, Hoi-yan CC. Attitudes to and practices regarding sex selection in China. Prenat Diagn. 2006;26(7):610-613.

167. Pinghui Z. Zhejiang man arrested for arranging sex tests in Hong Kong for pregnant mainland women. South China Morning Post. April 18, 2014.
International Journal of Women's Health

\section{Publish your work in this journal}

The International Journal of Women's Health is an international, peerreviewed open-access journal publishing original research, reports, editorials, reviews and commentaries on all aspects of women's healthcare including gynecology, obstetrics, and breast cancer. The manuscript management system is completely online and includes

\section{Dovepress}

a very quick and fair peer-review system, which is all easy to use. Visit http://www.dovepress.com/testimonials.php to read real quotes from published authors. 